\title{
Electronic Banking and Performance of Commercial Banks at I\& M bank Rwanda Ltd (formerly BCR), Rwanda
}

\section{Delphine Mushashi ${ }^{1}$, Osiemo Kengere ${ }^{2}$ and Dr Ernest Safari ${ }^{3}$}

\author{
${ }^{1,2}$ School of Business and Economics, Mount Kenya University, \\ Kigali, Rwanda \\ ${ }^{3}$ School of Hospitality Management, Mount Kenya University, \\ Kigali, Rwanda
}

\begin{abstract}
This study assessed electronic banking on performance of I\& M bank in Rwanda. A descriptive and correlational research designs were used. A sample size of 77 was drawn from 350 employees and customers of I\&M Bank. Data was collected using questionnaires, interviews and documentary review. Results show that $16 \%$ felt on automated teller machines, $22 \%$ for mobile banking, $13 \%$ for money transfers, $26 \%$ for access to account and $23 \%$ for credit card. Findings show that $78 \%$ testified the bank development. Results revealed that $46 \%$ said the bank had the large number of customers, $44 \%$ are satisfies with services and 10\% said I\&M Bank has enough and convenient facilities. Results on the relationship between electronic banking and performance demonstrated significant correlations between Automated Teller Machines and institutional reputation $\left(\mathrm{r}=.215^{*}, \mathrm{p}=.048\right)$, number of customers $\left(.512^{*}, \mathrm{p}=0.036\right)$ and service delivery $\left(\mathrm{r}=.546^{*}, \mathrm{p}=.023\right)$. Insignificant correlation was between Automated Teller Machines and competitiveness $\left(r=.244^{*}, \quad \mathrm{p}=.346\right)$. Negative correlations were between access to account and institutional reputation $(\mathrm{r}=.391, \mathrm{p}=.120)$. The research concludes that electronic banking and performance are correlated. The study recommends that all commercial banks should put emphasis on electronic banking to perform well.
\end{abstract}

Keywords: Electronic Banking, Performance, Commercial Bank

\section{Introduction}

Internet banking permits bank clients to access their accounts, so that they may be aware which amount is credited or debited in bank account which in turn help to solve problems whether any. Many factors comprising of competitive cost and customer service are stimulating banks to assess their technology and identify their internet banking practices. Internet banking permits widened customer contact through increased geographical reach and lower cost provision channels. In fact, some banks are doing business exclusively through internet they do not have traditional banking offices and only reach their customers online. I\&M Bank Rwanda Ltd (Formerly BCR) introduced e-banking in its operations which mainly include using internet and short message service (SMS) so that customers may be banking away from the bank without the hassle of physically going there.

Many banks that delayed to introduce e-banking or have limited features of internet banking have encountered problems in winning customer loyalty thus limited performance since performance of commercial banks are mainly due to the number and loyalty of customers. This therefore means that electronic banking has a proposal on the performance of commercial banks. However, there is need to ascertain the extent of the effects of electronic banking had on the performance of commercial banks in Rwanda. All the above considerations led the researcher to find the effect of electronic banking on the performance of commercial banks with reference to I\&M Bank (Rwanda) Ltd - formerly BCR

\section{Review of Literature}

In information driven business climate, firms which did not adopt e-banking are at a competitive disadvantages. The business owners, accountants and other approved workers may access repetitive banking activities like deposits, cleared checks and wired funds quickly through an online banking interface. This ease of review supports ensure the smooth processing of all bank transactions on a daily basis, rather than waiting than for monthly statements. Mistakes or delays may be noted and set 
quickly, clearly before any business effects is felt (Barth and Levine, 2001).

E-banking stimulate the production benefits, automating repetitive bill payments, reducing the expect to physically visit the bank and the ability to work as needed rather than on banking hours may reduce the time included in executing routine banking activities. Business that tool pace more needs on banking workers and need more tangible support with wire transfers, deposits, study ask and other banking activities usually sustain higher fees. Opting for e-banking reduces business and banking costs (Berg, and Zettelmeyer, 1999).

The utilization of e-banking decreases banking errors. Automation of payments, wires or other consistent financial activities confirms payments were mad on time and might eliminate mistakes produced by keyboard slips or user error. E-banking provides visibility into banking actions that makes it harder for under the table of fraudulent actions to appear (Alter, 2002). Internet banking permit bankers to follow up customers 'accounts simultaneously if they have been with their headquarters. Providing financial services electronically is seen as an alternative provision way rather than an extra to the brick and mortar banking services (Carlson, 2001).

Most of these services include payment of bills, funds transfer, viewing account statement, etc. Banks also supply their latest products and services over the internet. Internet banking is successes via a computer system or the same devices that may link with the banking site through internet (Carlson, 2001).

Even whether one is vacation halfway across the world, may carry out banking as long as he or she has a computer and internet access. ATM's permit one to deposit or withdraw money without stepping foot in a bank access Bills: most bills may be paid online by signing up various billing accounts so that they are paid from bank account. This link is made through online banking where one can then set up automatic payments that debit the, money through online banking where one then set up automatic payments that debit the money immediately from the account (Walfried, 2005).

E-Money, calculated in the currency unit kept in eform on e-device in the client' ownership. This evalue may be obtained and seized on the means until decrease according to goods or services. Erecruitment service given to customers like (Army, navy, police and paramilitary) via www and using scrape card and PINs for a probably aspirants purchase cards, visiting portal and complete adequate (Berg and Zettelmeyer, 1999).
ISSN 2455-6378

Mobile baking consist of proving client the accessibility to services as ongoing. Client ,may perform their businesses every time and in any place like account balance sheet, inquiry, stopping checks, and other client services, verifying account, paying bills, e-fund transmission, historical statement and transfer between customers' account (Walfried, 2005).

In some instances financial sectors continue to be low other have improved their performance or are striving to perform well (Barth and Levine, 2001). The performance of a firm is determined by several factors. During the past few decades the banking sector around the world experienced reflective regulatory and technological adjustments. Advanced applications in computer and communication technology together with the introduction of new financial tools have changed the way banking is carried out. Like modifications clearly changed the technology of bank production (Alter, 2002).Owing to this bank management and boards are responsible for serving their societies, attaining acceptable shareholder returns and defensive the interests of depositors, they need to ensure that the loan portfolio gives consistent reasonable income (Carlson, 2001). Good success ranking, on other hand, not only encourage admiration, they stimulate imitation and competition that tend to grid down a favorable position (Walfried, 2005). The main opinion is that any characteristic of organizational practice that may give competitive advantage is normally used by all competitors (Carlson, 2001).The present performance appeared sometime back-first with decisions and then actions that followed the decisions. Profit is this an indicator of previous success. In this context, performance is the outcome or end (Carlson, 2001).

According to Haron (2004), commercial banks that have as one of their objectives to be most profitable firm in this sector will have the main performance indicators that assess profit and associated fiscal in this sector. ICT become an epicenter of this worldwide transformation turn of e-banking currently. The use of information and communication technology concepts techniques, policies and the execution strategies to banking services has become a subject of basic role and issues to all banks and indeed the necessities for local for local and global competition among banks. This is establishing cash less society where consumers no longer had to pay for all their purchases with hard cash (Samad, 2004). The bank customers may pay for airline tickets and promise to start public provision by moving the money immediately from their accounts or pay for different goods and services by electronic transfers of credit to the sellers account (Bartlett \& Higgins, 2001). 
In fact, as well as many persons and customers of banking institutions have mobile phones, it become easy to transaction with banks where mobile banking enable them to know the situation on their bank accounts, withdrawing and transferring money via mobile phones (Haron, 2004). Internet banking services facilitates banks to decrease operational expenses, lowering, extra costs, attaining economies of scale and enhanced productivity. The e-banking extreme potential refers to timelier, relevant data obtainable to many customers. At low cost of accessing to data(Carlson, 2001).

Many scholars and writers have talked about the effects and benefits of internet banking in commercial banks but have not clearly shown how electronic banking can positively impact the performance of commercial banks. There is need to show why commercial banks are mainly concerned about improvements in banking industry and introduction of electronic banking by showing how it affects performance.

\section{Materials and Methods}

The population of the research was 120 employees and 230 customers of I\&M Bank Rwanda. The study considered 230 customers. It took all employees because they understood the performance of the bank and its attributes. The sample size of the research was 77 including 26 employees and 51 customers of I\&M Bank selected using purposive sampling. The study drafted clear and specific questionnaires containing questions on electronic banking and performance of commercial banks. The study adopted interview.

\section{Results and Discussion}

The study presented the views of respondents in relation to the features of electronic banking so as to facilitate making of relevant conclusions in relation to the study

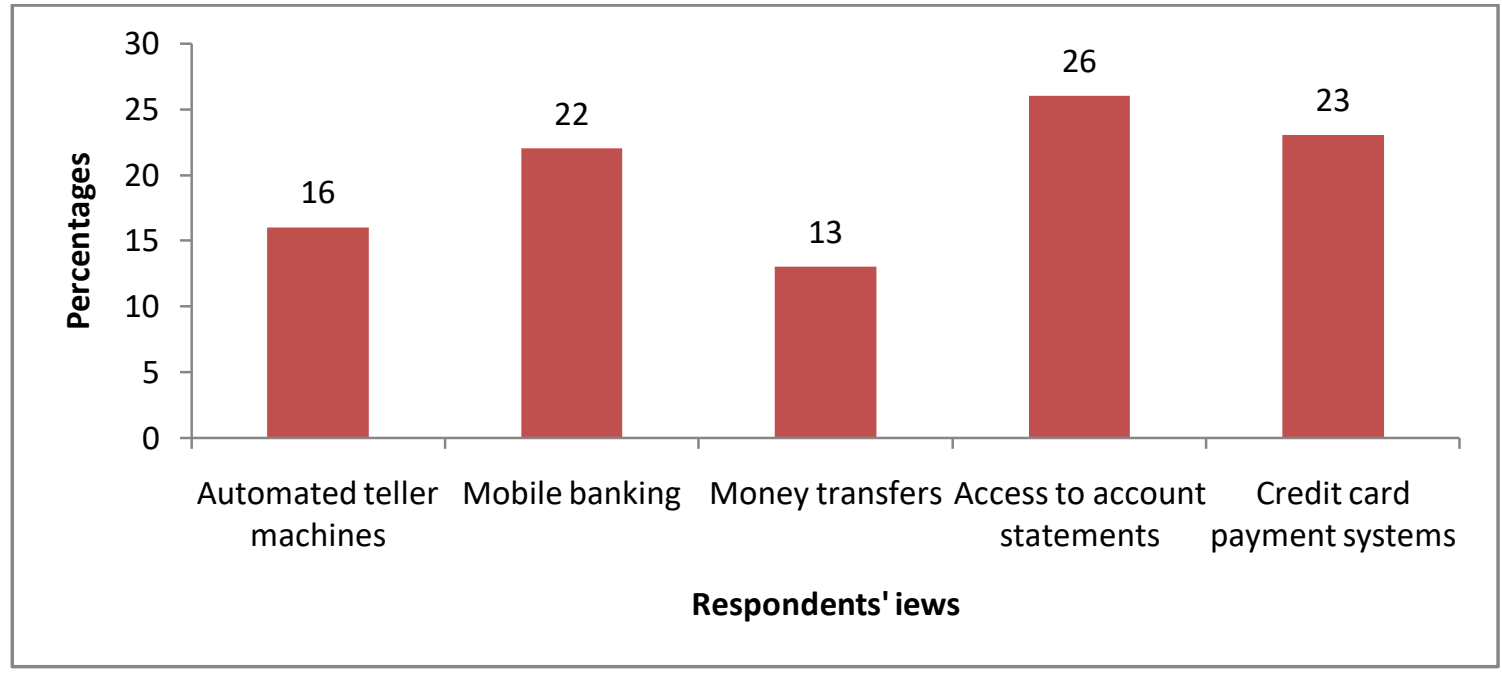

Figure 4.1: The features of electronic banking in I\&M Bank

Results presented in Figure 4.1 indicate that $16 \%$ of respondents confirmed the used of automated teller machines, $22 \%$ said mobile banking, $13 \%$ said money transfers, $26 \%$ said access to account statements and $23 \%$ said credit card payment systems.

Table 4.1: How electronic banking has helped I\&M Bank Rwanda to perform better

\begin{tabular}{lcc}
\hline Benefits of electronic banking & Frequency & Percentage \\
\hline Easy to use & 5 & 15 \\
It saves time & 7 & 27 \\
Can be done across borders & 5 & 19 \\
It increases customers & 6 & 24 \\
Improves competitive power of the bank & 4 & 15 \\
\hline Total & $\mathbf{2 6}$ & $\mathbf{1 0 0}$
\end{tabular}


The benefits of electronic banking in I\&M Bank are being easy to use (15\%), $27 \%$ said it saves time and $19 \%$ said it facilitates banking across borders. $24 \%$ said it increases customers and $15 \%$ said it improves competitive power of the bank. It was concluded that the benefits of electronic baking are geared towards ensuring that customers are catered for while at the same time the bank is benefiting in terms of performance and development.

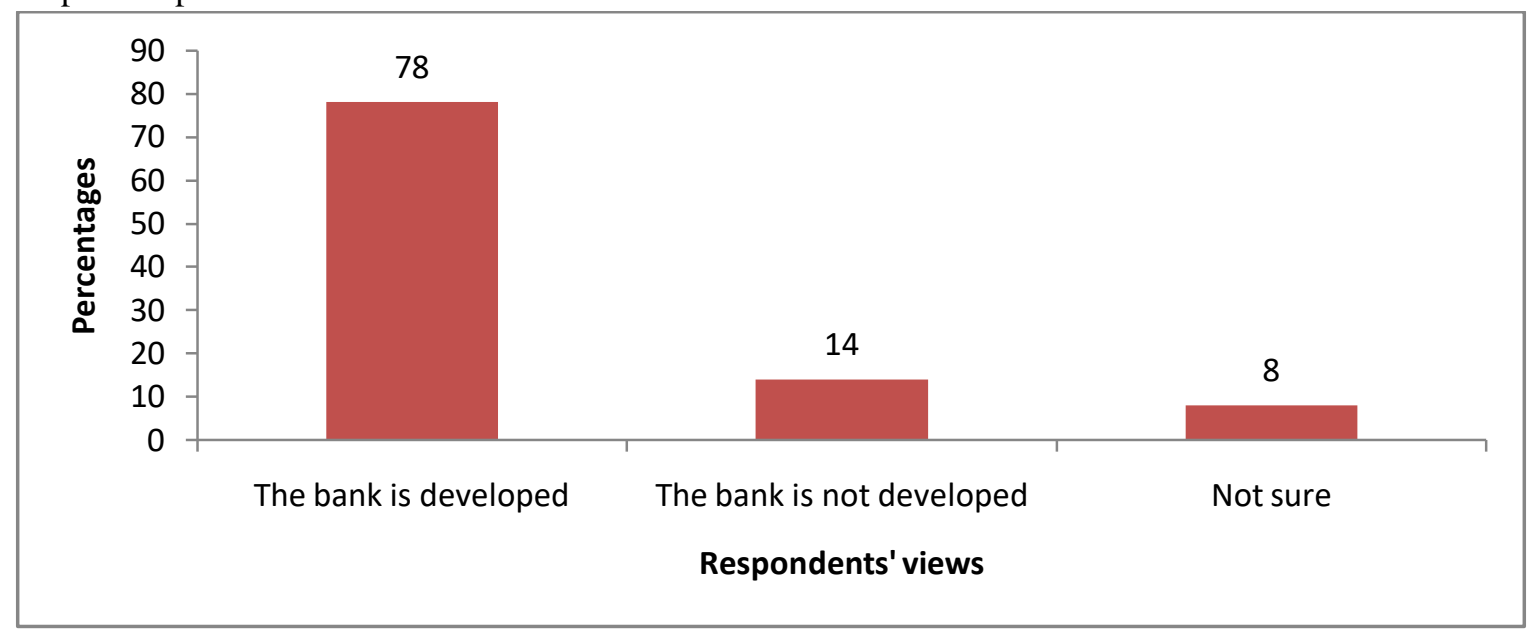

Figure 4.2: Respond nets views on whether I\&M Bank Rwanda Ltd (Formerly BCR) is developed or not

Results revealed that the bank is developed (78\%) while $14 \%$ of respondents said the bank is not developed and $8 \%$ said they were not sure. When respondents were requested to provide opinions for their responses, they said the bank had the large number of customers $(46 \%)$ while $44 \%$ of respondents said the clients of the bank are satisfies with the services given and $10 \%$ of respondents said I\&M Bank Rwanda Ltd has enough facilities that are convenient. It was seen that the electronic banking has set the bank on edge with multiple benefits geared towards performance of the institution.

Table 4. 2 Correlation between Electronic Banking and Performance of Commercial Banks at I\&M Bank

\begin{tabular}{|c|c|c|c|c|c|c|}
\hline & & & $\begin{array}{l}\text { Improved } \\
\text { institutional } \\
\text { reputation }\end{array}$ & $\begin{array}{l}\text { Increased } \\
\text { competitiveness }\end{array}$ & $\begin{array}{l}\text { Increase in the } \\
\text { number of } \\
\text { customers }\end{array}$ & $\begin{array}{l}\text { Improved } \\
\text { service } \\
\text { delivery }\end{array}$ \\
\hline \multirow[t]{3}{*}{$\begin{array}{l}\text { Use of automated } \\
\text { Teller Machines }\end{array}$} & $\begin{array}{l}\text { Pearson } \\
\text { Model }\end{array}$ & Correlation & 215 & .244 & $.512^{*}$ & $.546^{*}$ \\
\hline & Sign. (2-t & illed) & .048 & .346 & .036 & .023 \\
\hline & $\mathrm{N}$ & & 77 & 77 & 77 & 77 \\
\hline \multirow[t]{3}{*}{ Mobile Banking } & $\begin{array}{l}\text { Pearson } \\
\text { Model }\end{array}$ & Correlation & -.308 & $.680^{* *}$ & $.931^{* *}$ & $.558^{*}$ \\
\hline & Sign. (2-t & iled) & .229 & .003 & .000 & .020 \\
\hline & $\mathrm{N}$ & & 77 & 77 & 77 & 77 \\
\hline \multirow[t]{3}{*}{ Money transfers } & $\begin{array}{l}\text { Pearson } \\
\text { Model }\end{array}$ & Correlation & $-.523^{*}$ & $-.637^{* *}$ & $.986^{* *}$ & $.643^{* *}$ \\
\hline & Sign(2-ta & (ed) & .031 & .006 & .000 & .005 \\
\hline & $\mathrm{N}$ & & 77 & 77 & 77 & 77 \\
\hline \multirow[t]{3}{*}{ Access to account } & $\begin{array}{l}\text { Pearson } \\
\text { Model }\end{array}$ & Correlation & -.391 & -.301 & .443 & .205 \\
\hline & Sign.(2-tc & led) & .120 & .241 & .075 & .431 \\
\hline & $\mathrm{N}$ & & 77 & 77 & 77 & 77 \\
\hline
\end{tabular}

*Correlation is Significant at the 0.5 level (2-tailed)

**. Correlation is Significant at the level 0.01(2-tailed). 
There significant correlations found between Automated Teller Machines and institutional reputation $\left(\mathrm{r}=.215^{*}, \mathrm{p}=.048\right)$, and number of customers $(.512 *, \mathrm{p}=0.036)$ and service delivery $\left(\mathrm{r}=.546^{*}, \mathrm{p}=.023\right)$. These correlations were ssignificant given that the $\mathrm{p}$ value was $<0.05$ suggesting that an increase the use of Automated Teller Machines leads to the improvement in institutional reputation, in number of customers, and improvement in improved service delivery and the vice versa. Contrary, there is insignificant correlation found between Automated Teller Machines and competitiveness $\left(r=.244^{*}, \mathrm{p}=.346\right)$, this correlation is statistically insignificant given that the $p$ value was $>0.05$ suggesting that an increase in use of Automated Teller Machines did not increase competitiveness and the vice versa.

For mobile banking and number of customers $\left(\mathrm{r}=.931^{* *}, \mathrm{p}=0.000\right)$ and service delivery $\left(\mathrm{r}=.558^{*}\right.$, $\mathrm{p}=.020)$ were correlated. Insignificant correlation was between mobile banking and institutional reputation. Given that the $\mathrm{p}$ value was $>0.05$ suggesting that an increase in mobile banking did not affect institutional reputation.

There is an insignificant correlations between money transfers and institutional reputation ( $\mathrm{r}=-.523^{*}$, $\mathrm{p}=.031$ ). Significant positive correlations were between money transfers and number of customers $\left(\mathrm{r}=.986^{*}, \mathrm{p}=.0 .000\right)$ and iservice delivery $\left(\mathrm{r}=643^{* *}\right.$, $\mathrm{p}=005)$ given that the $\mathrm{p}$ value was $<0.05$ suggesting that an increase in money transfers increase in the number of customers but also improved service delivery and the vice versa.

Negative correlations were between access to account and institutional reputation $(\mathrm{r}=.391, \mathrm{p}=.120)$, between access to account and competitiveness ( $\mathrm{r}=-$ .301, $\mathrm{p}=.241$ ). Moreover, a positive correlation was between access to account and number of customers $\left(\mathrm{r}=.443^{*}, \mathrm{p}=.075\right.$ and access to account and service delivery $(\mathrm{r}=.205, \mathrm{p}=.431)$.

\section{Discussion}

This study conformed the work of (DeYoung,2015) who observed that the business owners, accountants and approved workers may access repetitive banking activities like deposits, cleared checks and wired funds quickly through an online banking interface.

\section{Acknowledgments}

I wish to acknowledge Mr. Osiemo KENGERE and Dr Ernest SAFARI for having sacrificed his time and other commitments to guide me throughout the writing of this research. In addition to that, I thank the staff and management of Mount Kenya University for their academic support. I cannot forget to thank the entire staff of I\&M Bank Rwanda Ltd for having accepted me to do my research from the institution
ISSN 2455-6378

The study was made to understand that the bank has various features of electronic banking that have simplified banking activities leading to improved bank performance.

Findings felt with previous studies, for instance, the banking industry in different economic sectors have recognized main changes. In some instances financial sectors continue to be low other have improved their performance (Nyangosi \& Arora,2010). It was seen that the electronic banking has set the bank on edge with multiple benefits geared towards performance of the institution.

This study contracts the findings of Kumbhar (2012) who asserts that the use of electronic banking is stimulate institutional reputation, increased competitiveness, increase in the number of customers and improved service delivery and demonstrated a strong correlation in all parameters of financial performance of commercial banks. However, results from the present study indicate insignificant correlation

\section{Conclusions}

It was concluded that the features of electronic banking in I\&M Bank are automated teller machines; mobile banking, money transfers, access to account statements and credit card payment systems and that the bank was stimulated to employ electronic banking by the need to satisfy customers, other banks were using it, market competition, it is convenient and it facilitates bank performance.

The factors affecting performance of I\&M Bank Rwanda Ltd is good owing to the use of electronic banking and factors affecting performance of I\&M Bank Rwanda Ltd are the size of customer, market competitiveness, commitment of employees, multiple services provided by the bank and the quality of services given.

Electronic banking and performance of commercial banks are positively correlated, the concerned stakeholders had benefited from electronic banking and still feel more should be done in order to continue improving the success of commercial banks through electronic banking and the respondents appreciate the contribution of electronic banking on the performance of commercial banks.

\section{Reference}

[1] Alter, S. (2002), "Information Systems" 4th Edition, Prentice Hall

[2] Banan, M. (2008). The viewpoint of bank's staff about internet banking. 3rd international conference on E-commerce with focus on developing countries. Isfahan.

[3] Barth, J., and Levine, R. (2001). Bank Regulation and Supervision: What Works Best? unpublished manuscript. 
[4] Bartlett, 1. \& Higgins, M. (2001). "Organizational research: Determining appropriate sample size for survey research

[5] Berentsen, A. (1998), Monetary Policy Implications of Digital Money, Kyklos, Vol. 51, pp. 89117.

[6] Berg, A., Borensztein, R. and Zettelmeyer, J.(1999). The Evolution of Output in Transition Economies - Explaining the Differences. IMF Working Paper No. 99/73.

[7] Berg, A., Forsund, L. Hjalmarsson, and Suominen, M. (1930). Banking Efficiency in the Nordic Countries, Journal of Banking \& Finance, vol. 17, no. 2-3, pp. 371-388.

[8] Berry, A. (1999), Mastering Data Mining: The Art and Science of Customer Relationship Management. New York: John Wiley \& Sons. pp.57-61

[9] Carlson, K. (2001). Internet Banking: Market Developments and Regulatory Issues. Society of Government Economists Conference 2000. Washington, $D C$

[10] Cohen, L. Benjamin J., (2001), Electronic Money: New Day or False Dawn? Review of International Political Economy, Vol. 8, pp. 197-225

[11]Cooper, S. and Tone, K. (2000). Data Envelopment Analysis. Kluwer Academic Publishers, Norwell, MA.

[12] Creswell, J. (2012). Educational research: Planning, conducting, and evaluating quantitative and qualitative research. Upper Saddle River, NJ: Prentice Hall.

[13]Demirguc, K. and Huizinga, K. (2000). Financial Structure and Bank Profitability, The World Bank mimeo.
[14] Gillham, B. (2008). Developing a questionnaire (2nd ed.). London, UK: Continuum

[15] Haron, S. (2004), Determinants of Islamic Bank Profitability, The Global Journal Finance and Economics, Vol., 1, No. , 1, pp 2-18

[16] International Publishing Group Ltd.

[17] Jen-Her Wu, H. (2006). Core Capabilities for Exploiting Electronic Banking. Journal of Electronic Commerce Research, 111-122.

[18] Kirkwood, L. (2010). The UFAW Handbook on the Care and Management of Laboratory and Other Research Animals. Wiley-Blackwell

[19] Laeven, L and Majnoni, G. (2003): "Loan loss provisioning and economic slowdowns: too much, too late?" Journal of Financial Intermediation, vol 12, no 2, pp 178-9

[20] Philip, D. and Haibin, Z.(2005), Commercial property prices and bank performance, Bank for International Settlements,working paper, no. 175 .

[21] Samad, A. ( 2004 ) Bahrain's Commercial Bank Performances During 1994-2001, Credit \& Financial Management Review ( working paper )

[22] Sullivan, R. (2000). How has the adoption of Internet banking affected performance and risk in banks? Financial Industry Perspectives, Federal Reserve Bank of Kansas City, Kansas. $1-16$.

[23] Toni, U. ( 2008), Determinants of Bank Profitability: Macroeconomic Evidence from Nigeria, Deakin university.

[24] Walfried, M. (2005), "The relationship between consumer innovativeness, personal, characteristics, and online banking adoption", International Journal of Bank Marketing; Volume: 23 